\title{
Phanerozoic Basin Evolution in North America
}

\section{by Albert W. Bally}

This article sketches the genesis of the sedimentary basins of the U.S.A. in terms of plate tectonics. This continent is but $a$ fragment that separated from a mythical Late Proterozoic supercontinent during the Cambrian and Early Ordovician. Continental collisions beginning in the Middle Ordovician and ending early in the Permian re-integrated North America into a new supercontinent, Pangea, which broke up again in Early Jurassic times to form the isolated North America plate we know today.

\section{The Late Proterozoic Supercontinent and Its Breakup}

Different versions of a Late Proterozoic supercontinent have been proposed (Morel and Irving, 1978; Piper, 1983 and 1987). Its fragmentation may well have been protracted over $200 \mathrm{Ma}$, but according to the subsidence studies of Bond and others (1984), it is reasonable to assume that the main breakup occurred between 600 and $550 \mathrm{Ma}$. The Cambrian to Lower Ordovician Sauk sequence (Sloss, 1963 and 1987) suggests that North America was entirely surrounded by oceans and rimmed by a passive margin with a fairly continuous carbonate shelf edge (Clark and Stearn, 1968; Cook and Bally, 1975; Ziegler et al., 1979). Remarkably, by Middle Ordovician time most of the interior of the continent was covered by shallow water carbonates, as witnessed by remnants of Middle Ordovician platform carbonates in Hudson Bay.

\section{North America Joins the Pangea Supercontinent}

The Innuitian-Caledonian-Appalachian-Ouachita folded belt begins in northern Alaska, where it forms the basement of the North Slope basin (Figs. 1, 2). From there the Paleozoic folds can be followed across the Arctic islands of northern Canada, across eastern Canada and the eastern U.S.A., into the southern U.S.A. (Williams, 1984) and Mexico where again Paleozoic deformed rocks form the basement. Associated clastic-filled foredeeps occur on the continent side of almost the entire Paleozoic folded belt. These foredeeps are due to lithospheric flexure under the load of stacked overthrust sheets (Quinlan and Beaumont, 1984; Beaumont et al., 1987). The allochthonous thrust complex involves Paleozoic sediments, as well as the Precambrian basement and various terranes representing fragments of small continents and volcanic ares (see Rodgers, this issue).

The sedimentary record of the Paleozoic foredeeps reflects the ongoing orogenic activity in the hinterland. Thus, in the Appalachian Basin a late Upper Ordovician to early Upper Silurian clastic wedge indicates ongoing Taconic deformations, while Devonian to Permian clastic wedges reflect Acadian and Alleghanian tectonism. The continuous subsidence of the basin suggests secular orogenic shortening in the adjacent folded belt. The Paleozoic foredeep of the southern U.S.A. clearly responded to Mississippian and Pennsylvanian deformation in the Ouachita-Marathon folded belts (Nicholas and Rozendal, 1975).

Paleozoic deformation in the western cordillera began during the Siluro-Devonian with a postulated island arcbackarc basin complex located somewhere outside the North
American continent (Poole et al., in Stewart et al., 1977). During Mississippian times much of the backarc basin was inverted and deformed to form the Antler orogenic belt with an associated foredeep sequence that later was involved in further deformation (Poole and Sandberg, in Stewart et al., 1977). Remnants of upper Paleozoic fold belts can be traced towards the north into the Canadian cordillera.

By end Mississippian, North America was rimmed in horseshoe-like fashion by late Paleozoic folded belts. Thus the continental interior was in effect segregated from the main oceans. L. Sloss (1963 and 1987) has subdivided the Paleozoic Era of North America into a number of unconformitybounded sequences. His Kaskaskia sequence (basal Siegenian $401 \mathrm{Ma}$, to basal Namurian $330 \mathrm{i} / \mathrm{a}$ ) is underlain by a subcrop configuration that reveals the immense NE-SW striking transcontinental arch (Fig. 3), which extends from Minnesota to the Grand Canyon area (Mallory, 1972; Bally, 1980). A subparallel arch formed at the same time in the Peace River area of NE British Columbia. A wavelength in excess of $2000 \mathrm{~km}$ between the two arches suggests poorly understood deep-seated mantle processes as a cause.

The subsequent Lower Absaroka sequence (base Namurian $330 \mathrm{Ma}$ to base Tatarian $253 \mathrm{Ma}$ ) is best represented by Pennsylvanian isopachs (Fig. 4, Cook and Bally, 1975) of SW U.S.A. These trend SE to NW, i.e. perpendicular to the strike of the earlier Transcontinental Arch, and are related to the final collisional events that led to the consolidation of Pangea. The SE-NW trend extends from Oklahoma across the Rocky Mountains into the area of Salt Lake City, where we can trace the "Ancestral Rocky Mountains" - a complex of basement-involved compressional and transpressional uplifts that are intimately associated with the adjacent, very deep Permo-Pennsylvanian sedimentary basins (see also Kluth and Coney, 1981).

By the end of Permian or early Triassic time, North America was firmly linked to Pangea, even though, at that time we already observe the beginnings of rifting events in north-western Europe, Greenland and Arctic Canada (Ziegler, in press). These herald the breakup of the Pangea super-continent.

\section{The Mesozoic-Cenozoic Evolution of North America}

As other articles in this issue show, the Mesozoic-Cenozoic was the time of formation of the passive margins of North America, the thick Tertiary deltaic sequences of the Gulf Coast, the formation of the western cordillera, its associated foredeeps, and the sedimentary basins of the U.S. west coast. Figure 5 shows the rock accumulation rates of a typical time slice (Late Cretaceous) to illustrate simultaneous subsidence of the Atlantic-Gulf of Mexico passive margin, the Rocky Mountain foredeep and the great valley of California.

Atlantic-type passive margins were created in different segments following a common Late Triassic-Early Jurassic rifting event (Manspeizer, 1985). The central Atlantic opened during the Middle Jurassic, and ocean-spreading continued at varying rates until today (Klitgord and Schouten, in Vogt and Tucholke, 1986). Iberia and the Rockall Plateau plus Norway separated during the Early and 


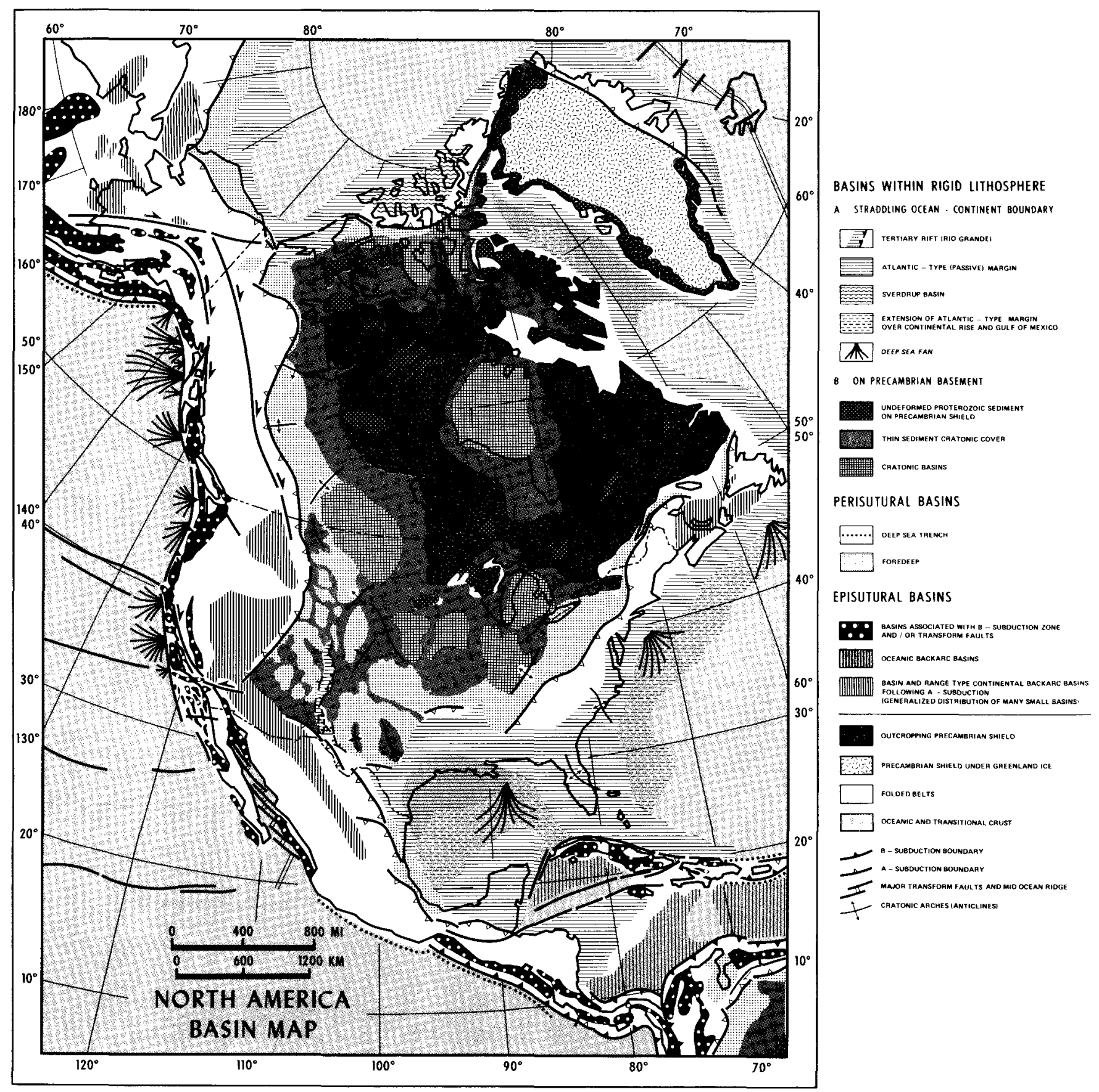

Figure 1: Basin types of North America. After Bally, (1980).

Late Cretaceous Period, respectively, and finally Spitzbergen separated from Greenland in Early Oligocene time (Srivastava and Tapscott, in Vogt and Tucholke, 1986). Thus, the U.S Atlantic passive margin exhibits rifts that are overlain by thick Middle Jurassic and younger sediments that record the combined effect of lithospheric cooling and flexuring due to the large sediment loads deposited on that margin (see Sheridan, this issue).

The Gulf of Miexico basin was initiated by a short oceanspreading phase during the Middle and/or Late Jurassic (Buffler and Sawyer, 1985; Salvador and Green, 1980). Earlier ancestral basins and rifts are known to have formed during the Pennsylvanian-Triassic interval. From the Jurassic to the Mid-Cretaceous the Gulf of Mexico was surrounded by extensive carbonate shelves that were later smothered by a very thick Tertiary deltaic clastic wedg'e (see Curtis, this issue).

Turning to the northern shelf of Alaska, we find a passive margin that formed as the consequence of the opening of the Beaufort Sea between Albian and Maastrichtian time. This was preceded by a distinct rifting phase that extended from the Early Jurassic into the Neocomian (Hubbard et al., 1987 , see also Stone and Wallace, this issue).

The western cordillera is viewed by many as the product of diffuse deformation in a transpressive setting which, for the U.S.A., was due to the convergence of a northwesterly and later westerly drifting North America plate with an easterly and then northwesterly drifting Farallon plate (Dickinson, in Armentrout et al., 1979; Dickinson and Snyder, 197 ; Engebretson et al., 1985, and see Hamilton, this issue). The result of the convergence is an eastern cordillera that is 


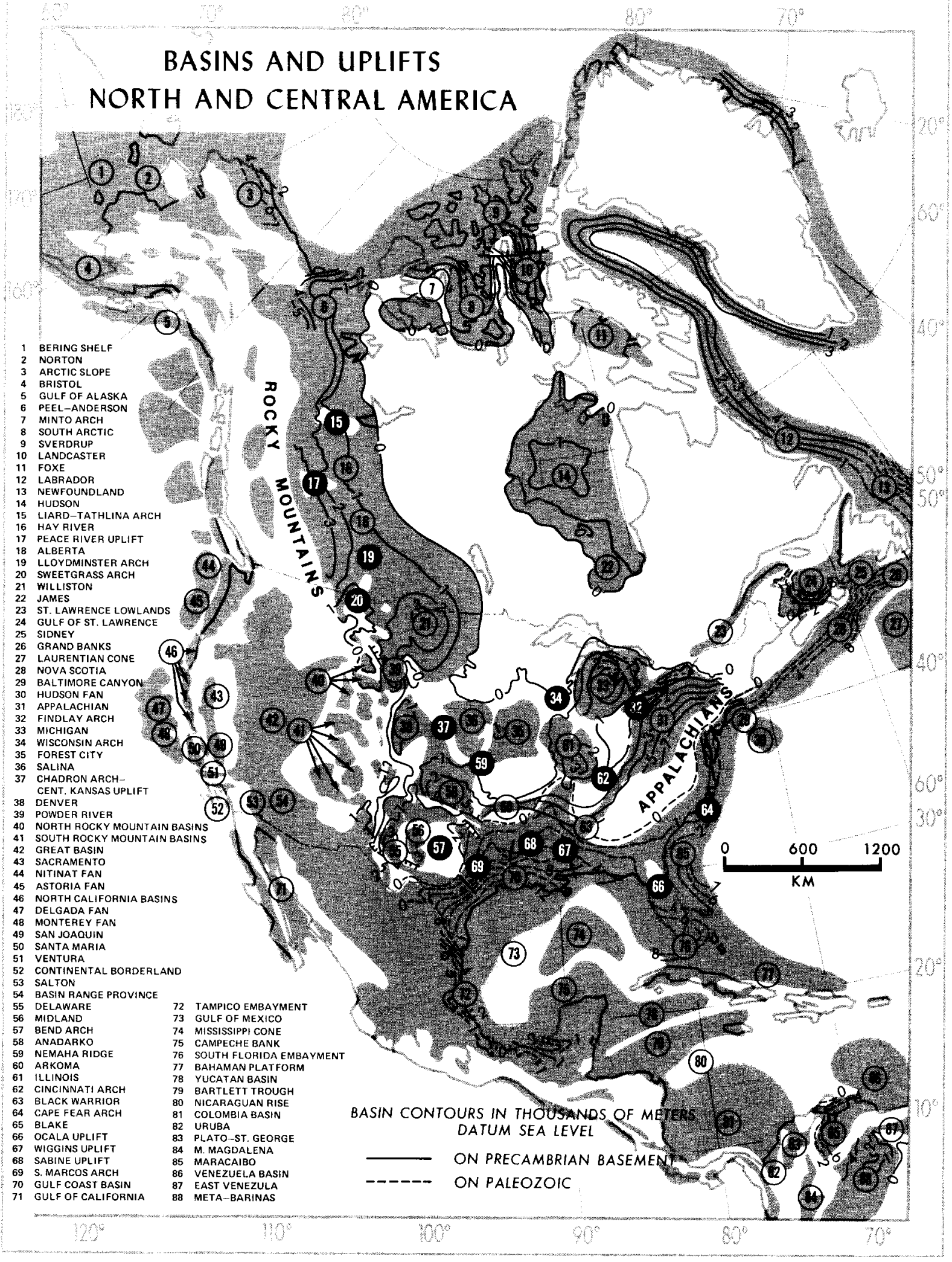

Figure 2: Basins (open circles) and uplifts (black circles) of North and Central America. Note that the scale of the map only permits depth to basement to be shown under the cratonic and passive margin portions of North America. 


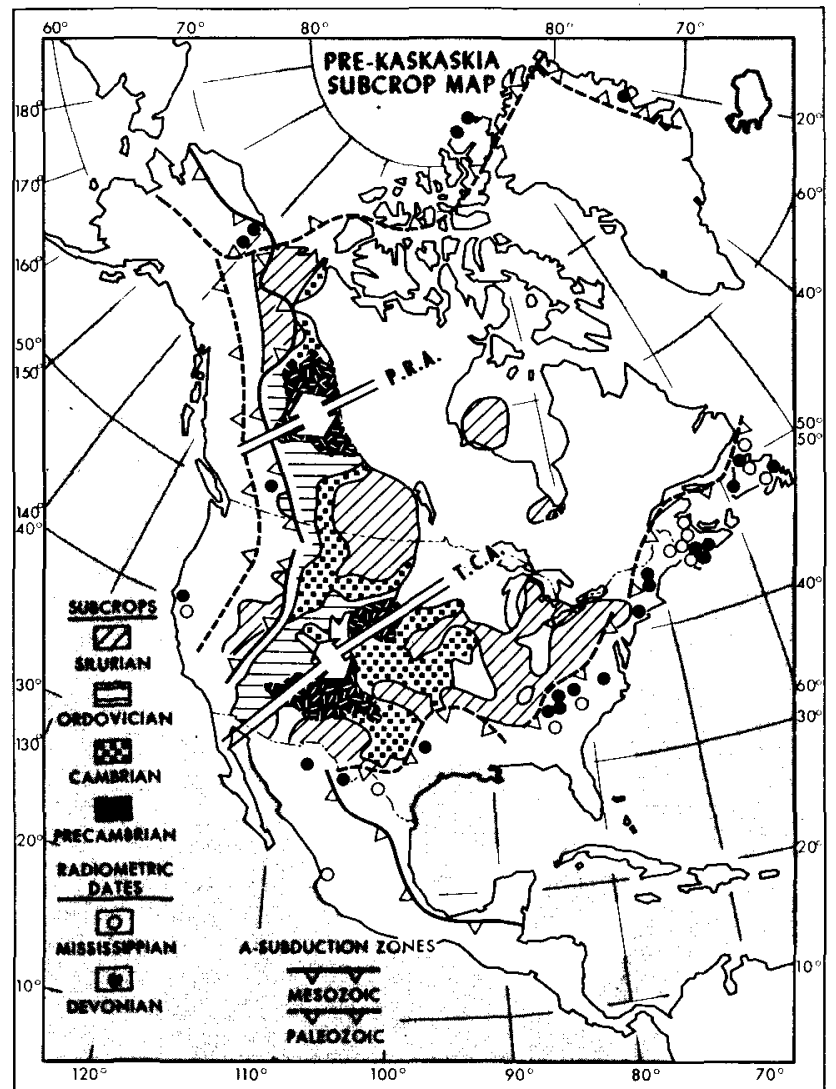

Figure 3: Pre-Kaskaskia subcrops. This map shows the distribution of early Paleozoic beds below the unconformity at the base of the Devono-Mississippian Kaskaskia sequence (Bally, 1980). Note that the Precambrian core of the Transcontinental Arch (TCA) appears to be offset in left-lateral sense, suggesting a Pennsylvanian strike-silp system that extends from oklahoma toward the Salt Lake area of Utah. PRA - Peace River Arch.

formed by extensive overthrusts involving sediments and basement slices of an earlier Paleozoic passive margin. The associated subduction of continental and transitional mantle (and possibly lower erust) is referred to as A-subduction (Bally and Snelson, 1980). Serious overthrusting in the eastern cordillera began during the Middle Jurassic and ended in Early Eocene time. Subsidence of an asymmetrical Jurassic to Paleocene clastic-filled foredeep (Mallory, 1972; Cook and Bally, 1975; Reynolds and Dolly, 1983) is due to the flexural response of a lithosphere that is being loaded by multiple thrust sheets (Beaumont, 1981 and Stockmal et al., 1986).

In Alberta, the Rocky Mountain foredeep is underlain by an undisturbed mountainward-dipping monocline. However, in the U.S. Rockies this simple picture is modified by the occurrence of numerous compressional basement uplifts, which probably relate to a décollement system occurring within or at the base of the lower crust (Bally and Snelson, 1980). These uplifts break the Cretaceous foredeep into a large number of small but very deep basins that acquired their present identity during Late Cretaceous-Early Eocene time. Here the Tertiary subsidence may be explained by tectonic loading from basement-involved uplifts (Iiagen et al., 1985).

During most of the Mesozoic and the Tertiary the Pacific coast of the western cordillera was dominated by subduction of the Farallon and Pacific plates (Dickinson, in Armentrout et al., 1979; Dickinson and Snyder, 1978; Engebretson et al., 1985, and see Crowell, this issue). This led to the formation of Franciscan-type accretionary wedges and during much of the Middle and Late Jurassic and the Cretaceous, to the island arc-related Sierra Nevada batholiths. This is the setting of the Late Jurassic to end-Cretaceous fore-are basin of California's Great Valley.

The Mid-Oligocene marked the beginning of profound structural changes in the western U.S.A. (Armentrout et al., 1979; Engebretson et al., 1985; Page and Engebretsen, 1984; and Ingersoll and Ernst, 1987). The Pacific-Farallon ridge arrived at the coast of southern California, leading to the Neogene development of the San Andreas dextral transform system. Associated pull-apart basins formed, perhaps as early as the mythical Paleogene proto-San Andreas (Nilsen and Clarke, 1975; Nilsen and McKee, 1979), whereas other transtensional basins are related to the Neogene San Andreas system (Crowell, 1974, and this issue). Note that during Plio-Pleistocene times, all California basins were subjected to dramatic inversion tectonics as illustrated by wide-spread transpressional folding and thrust-faulting.

The marine clastic basins of California contrast with the coeval continental basins of the Basin and Range Province and the Rio Grande rift. Polyphase extensional tectonies that began during Middle Oligocene time led to the formation of a complex system of listric-norinal and transfer faults that delineate a very large number of transtensional basins (Eaton, 1982). Unlike the California basins, transpressional inversion is virtually absent in the Basin and Range province, suggesting very effective decoupling of the San Andreas fault system from the main continent during the Neogene.

To complete the picture, note that the forelands of the eastern Rocky Mountains and the Colorado Plateau have been severely uplifted since Mid-Oligocene times (Curtis,

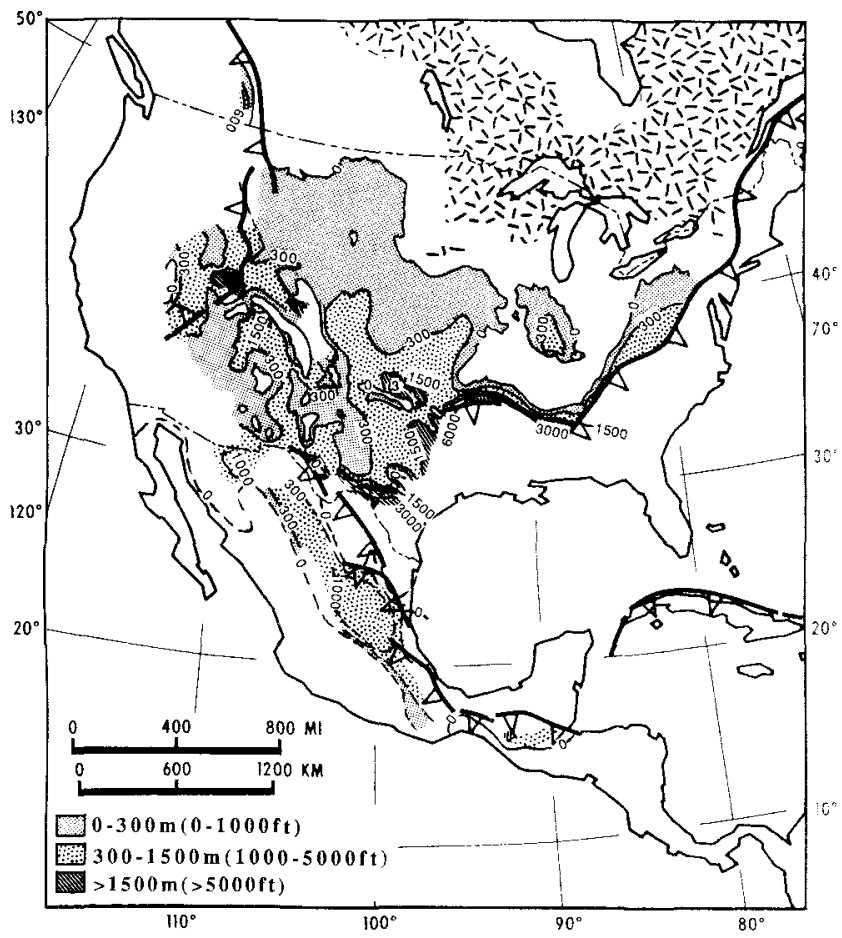

Eigure 4: Pennsylvanian isopachs of the U.S.A. (after cook and Bally, 1975). Note that the overail strike of the Pennsylvanian isopachs is approximately perpendicular to the strike of the transcontinental arch. The NW-SE trending Pennsylvanian basins are related to basement-involved transpressional foreland tectonics. 
1975; Flores and Kaplan, 1985), so that the clastic detritus of the eastern Rocky Mountains was no longer trapped in foredeep basins. Instead detritus was transported toward the Gulf of Mexico where it contributed to the formation of very thick systems of Oligocene to Neogene deltaic clastics (Winker, 1982).

\section{Basin Subsidence and Seismic Stratigraphic Cycles}

In recent years seismic sequence stratigraphy (Sloss, 1963 and 1987; Vail et al., 1977, 1984 and in press; Bally, in press) and basin model studies (e.g. Beaumont, 1981, Beaumont et al., 1987; Quinlan and Beaumont, 1984; Watts et al., 1982, 1984) have been combined to modify radically traditional stratigraphic thinking. There is a broad consensus that many U.S. basins (e.g. Atlantic margin, the Mesozoic Gulf of Mexico and the continental shelf of northern Alaska) owe their subsidence to cooling and sediment-loading following a lithospheric thermal-stretching event. Subsidence in other basins (e.g. the Paleozoic Appalachian-Ouachita foredeep, the Jurassic-Paleocene Rocky Mountain foredeep and the North Slope basin of Alaska) is due to lithospheric flexure in response to loading by multiple thrust sheets and/or by loading of basement overthrusts (e.g. Colorado-WyomingNew Mexico-Rocky Mountains and the Paleozoic Arkoma and Anadarko basins of Oklahoma).

Some of the near-circular cratonic basins of North America, (e.g., the Michigan, Illinois, Williston, and Hudson Bay basins, see Fig. 2) acquired their identity during midPaleozoic time. Their origin remains enigmatic, but their subsidence may well be due to cooling that followed, as yet poorly documented thermal events. Paleozoic sequence stratigraphy is particularly well displayed in these cratonic basins (Sloss, 1963 and 1987).

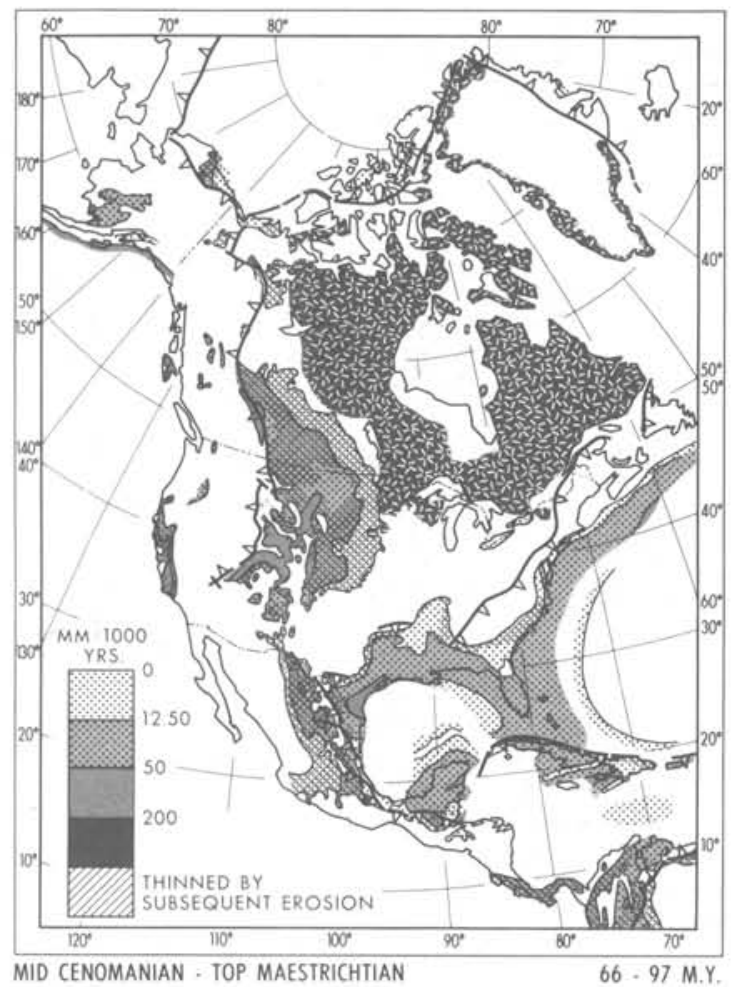

Figure 5: The accumulation of Upper Cretaceous rocks. This map gives an approximate idea of major subsidence trends. Note the synchronous subsidence along the Gulf of Mexico-Atlantic margin, the Rocky Mountain foredeep, and the Great valley fore-arc basin of California.
Finally, subsidence of the Tertiary basins of the west coast of the U.S.A. and southern Alaska is tied to the mechanics of fore-arc basin formation and to transpressional and transtensional tectonies leading to the formation of "pull-apart" and "push-together" basins, which may be viewed respectively as miniature rifts and foredeeps that are tied to strike-slip fault systems.

A number of authors have suggested that the second-order seismic stratigraphic cycles that were originally proposed by Vail et al. (1977) reflect changes in plate-tectonic regimes (Bally, 1980; Watts et al., 1982, 1984; Summerhayes, 1986). However, cycles based on seismic stratigraphy now are translated by Haq et al. (1987) and Vail and others (in press) into global eustatic cycles that became apparent after the effects of secular subsidence were subtracted from classical seismic stratigraphic cycles.

In the light of this latest work, it now appears to this author that there is no obvious correlation between eustatic cyclity and the inception and cessation of perceived major platetectonic regimes in North America. Dating of structural events is typically much less precise than good stratigraphic dating, and therefore it may be best to take the position that the eustatic cycles being postulated by Vail (in Bally, in press) represent a rhythm, superposed on secular subsidence, that is due to plate tectonic processes and that results in the definition of seismic stratigraphic sequences.

Future stratigraphic research in the U.S.A. may focus on the better definition and paleontological documentation of sequences based on outcrop and seismic stratigraphic work. Theoretical models of basin subsidence and its relationship to plate tectonic processes may be combined with paleoclimatological studies. A major breakthrough has been the introduction of three-dimensional seismic profiling (Brown, 1986).

I anticipate that by the turn of the next century, earth scientists will have developed the capability to map seismically the detailed stratigraphy and structure of entire sedimentary basins in three dimensions and to model the flow of fluids within these basins in time and in space. The International Congress of 1989 will help in laying the conceptual and technical foundations for such basin studies in the 21 st century.

Prof. A.W. Bally is a petroleum geologist who had worked mostly in Canada and the U.S.A. He recently joined the Department of Geology and Geophysics at Rice University (P.O. Box 1892, Houston, TX 77521). Currently he and his students work on projects that involve the integration of reflection seismic profiles with surface and subsurface geology in the U.S.A., Canada, Brazil, Spain and Italy.

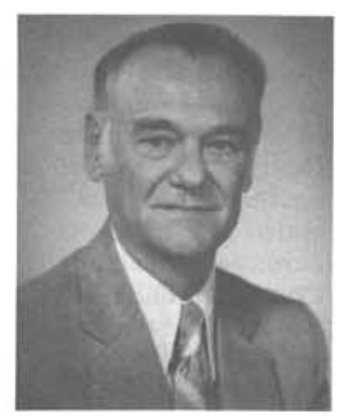


References

Armentrout, J.N., Cole, M.R. and Terßest, H., Jr., 1979. Cenozoic paleogeography of the western U.S. Symposium 3. Pacific Sectic
Society of Economic Paleontologists and wineralogists, 335p.

Bally, A.W., 1980. Basins and subsidence - summary. In: Bally, A.W. et al. (eds.), Dynamics of Plate Interiors. American Geophysica
Union, Geodynamies Series, v. 1, p. $1-20$.

Bally, A.W. (ed.), in press. Atlas of seismic stratigraphy. American Association.
volumes.

Bally, A.W. and Snelson S., 1980. Realms of subsidence. Canadian Society of Petroleum Geologists, i.lemoirs 6, p. 1-94.

Beaumont, C., 1981. Foreiand basins. Geophysical Journal of the Royel Astronomical Society, v. 65. p. 291-329.

Bequmont, C., Quinlan, G.M., and Hamilton, J., 1987. The Alleghanian Orogeny and its relationship to the evolution of the easter Eastern Canada and worldwide analogues. Canadian Society Petroleum Geologists Memoir 12

Bond, G.C., Nickerson, P.A. and Kominz, MA., 1984. Breakup of supercontinent between $625 \mathrm{Ma}$ and 555 Ma: new evidence and implications for continental hi

Brown, A.k., 1986. interpretation of three-dimensional seismic data. American Association Petroleum Geologists Memoir 42, $294 \mathrm{P}$.

Buffler, R.T. and Sawyer, D.S., 1985. Distribution of crust and early history, Gulf of Mexico Basin. Gulf Coast Association Geologica

Clark, T.H. and Stearn, C.W., 1968. The geological evolution of North America, 2nd ed. Ronald Press, 570p.

Cook, T.D. and Bally, A.W., 1975. Stratigraphic Atlas of North and Central America. Princeton University Press, 272p.

Crowell, J.C., 1974. Origin of late Cenozoic bosins in California. In Economic Paleontologists and Mineralogists, Special Publication p. 190-204.

Curtis, B.F., (ed.), 1975. Cenozoic history of the southern Rocky Mountains. Geological Society of America Memoir 144, $279 \mathrm{gp}$.

Diekinson, W.R. and Snyder, W.S., 1978. Plate Tectonies of the Laramide Orogeny. Geological Society of America Memoir 151, p.

Eaton, G.P., 1982. The Basin and Range province; origin and tec tonic significance. Annual Reviews of Earth and Planetary Seience,
v. 10, p. $409-440$. Engebretson, D.C., Cox, A. and Gordon, R.G., 1985. Relative motions between ocesnic and continental plates in the Pacific basin

Flores, R.M. and Kaplan, S.S. (eds.), 1985. Cenozoic paleogeography

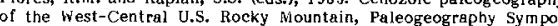

sium 3. Rocky Mountain Section, Society of Economic Paleontol-

llaq, B.U., Herdenbol, J. and Vail, P.K., 1987. Chronology of fluctuating sea levels since the Triassic. Science, v. 235, p. $1156-1167$.

Hagen, E.S., Schuster, M.W. and Furlong, K.P., 1985. Tectonic loading and subsidence of intermontaine basins, wyorning foreland province. Geology, v. 13, p. 585-592.

Hubbard, R.J., Edrich, S.P., and Rattey, P.R., 1987. Geologic evolution and hydrocarbon habitat of the Arctic Alaska microplale.

Ingersoll, R.V. and Ernst, W.G. (eds.), 1987. Cenozoie basin deve opment of coastal California. Rubey Volume G, Prentice Hall, 496p. Kluth, C.F. and Coney, P.J., 1982. Plate tectonics of the ancestral kocky hountains. Geology, v. 9, no. 1, p. $10-15$.

Mallory, W.W. (ed.), 1972. Geological atles of the Rocky Pountain region. Rocky Mountain Association of Geologists, 331p.

Manspeizer, W., 1985. Early Mesozoic history of the Atlantic passive margin. In: Poag, C.W. (ed.), Geologic Evolution

Morel, P. and Irving, Ec., 1978. Tentative paleocontinental maps for the early Phanerozoic and Proterozoic. Journal of Geology, v. 86

Nicholas, R.L. and Rozendal, R.A., 1975. Subsurface positive elements within Ouachita fold belt in Texas and their relation to Paleozoic cratonic margin. American
ogists Bulletin, v. 59, no. 2, p. 193-21 6 .

Nilsen, T.H. and Clarke, S.H., Jr., 1975. Sedimentation and Tectonies in the early continental borderland of Central California. U.S. Geological Survey Professional Paper 925, 64p.

Page, B.M. and Engebretson, D.C., 1984. Correlstion between the geologic record and computed plate motions for central California.

Piper, J.D.A., 1983. Proterozoic paleomagnetism and single continent plate tectonics. Geophysical Journal of the Royal Astronom-

Piper, J.D.A., 198?. Paleomagnetism and the Continental Crust. J. Wiley and Sons, $434 \mathrm{p}$.

Quinlan, G.M. and Beaumont, C., 1984. Appalechian thrusting lithospheric flexure, and the Paleozoie stratigraphy of the Eastern interior of North America. Canadian Journal of Earth Seiences, $y$ 21, no. 9, p. 973-996.

Reynolds, M.W. and Dolly, E.D. (eds.), 1983. Mesozoie paleogeography of the West-Central U.S., Symposium 2. Rocky Mountain Section, Society of Economic Paleontologists and Mineralogists,

Salvador, A. and Green, A.R., 1980. Opening of the Caribbean Tethys. In: Geology of the Alpine Chain born of the Tethys. Maemoir International Geological Congress, 25th Colloquium C5. Bureau de Recherches géologiques et minières, no. 115, p. 224-22.
Sloss, L.L., 1963. Sequences in the cratonic interior of North America. Ceological Society of America, v. 74, no. 2, p. 93-114. Sloss, L.L., 1987. Tectonic evolution of the craton in PreTertiary
Phanerozoic time. In: Sloss, L.L. et al., (eds.). Sedimentary cover of the eraton. Geological society of America. The Geology of North

Stewart, J.H. et al., 1977 (eds.). Paleozoic paleogeography of the Western United States. Pacific Section Society of Economic Paleontologists and Mineralogists, 235p.

Stockmal, G.S., Beaumont C. and Boutilier, R., 1985. Geodynamid models of converyent margin tectonics: transition from rifte margin to overthrust belt and consequences for foreland-towsin development. American Association Petroleum Geologists Bulietin v. 77, no. 2, p. $181-190$.

Summerhayes, C.P., 1986. Seatevel curves based on seismic stratigraphy: Their chronostratigraphic significance. Palaeogeography, Palaeoclimatology, Palaeoecology, v. 5i, no. 1, p. 27-42.

Vail, P.R., Witchum, R.M. and Thompson, S., IIt 1977. Seismic stratigraphy and globai changes of sea level, of sea level from coastal onlap. In: Payton, C.E. (ed.), Seismic straligraphy; applications to hydrocarbon exploration. Amerlean Association of Petroleum Geologists ifemoir 26, p. 63-81.

Veil, P.R., Hlardenbol, J. and Todd, R.G., 1984. Jurassic unconfor inities, chronostratigraphy, and sea-level changes from seisinic stratigraphy and biostratigraphy, In: Schlee, J.S. (ed.), Inter-reziont unconformiles and hycrocarbon accumulation. American Asose

Vogt, P.R. and Tucholke, B.E. (eds.). The Western North Atlantic region. Geological Society of Anerica. The Geology of North Amer

Watts, A.B. Karner, G.D. and Steckler, H.S., 1982. Lithospheric flexure and the evolution of sedimentary basins. in: Kent, P., it a (eds.), The evolution of sedimentary basins. Philosophical Trans-

Watts, A.B. and Thorne, J. 1984. Tectonics, global changes in sea level and their relationship to stratigraphic sequences at the Lis. Atlantic continental Margin. Marine and Petroleum Geology,

v. 1,no. 4, p. 319-339.

Williams, Hl., 1984. Miogeoctines and suspect terranes of the Cale donian-Appalachian Orogen; Tectonic patterns in the North Atiantic region. Canadian Journal of Earth Sciences, v. 21, no. 8, p. 887-901.

Winker, C.D., 1982. Cenozoic shelf margins, Northwestern Gulf of Mexico Basin. Gulf Coast Assoeiation of Geological Societies Transactions, v. 32, p. 427-448.

Ziegler, A.M., Scotese, C.R., Mickerrow, W.S., Johnson, M.E. an Bambach, R.K., 1979. Paleozoic paleogeography. Annual Review Earth and Planetary Science, v. 7, p. 463-502.

Ziegler, P., in press. Evolution of the Aretic-North Atlantic and Western Te

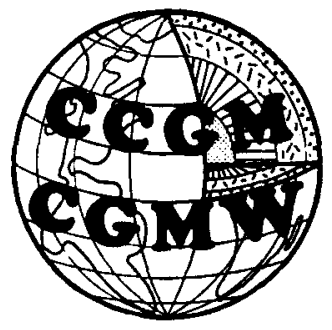

\section{Commission for the Geological Map of the World (CGMW)}

A non-governmental, international IUGS affiliate organizing and sponsoring the publication of

\section{G E O L O G I C A L M A P S}

Small-scale geological and thematic maps covering an entire continent in only 1 to 4 sheets.

Ideal for wall display in the classroom or office to give a complete overview of large areas under study in the laboratory or the field.

Attractive, easy to consult Geological World Atlas of continents and oceans in 22 sheets.

Write, phone or telex for free list of publications and outlets around the world.

CCGM / CGMW, 77 rue Claude-Bernard, 75005 PARIS - FRANCE

Phone: + .33.1.47.07.22.84 Telex 206411 F CGMW. 